\title{
Georgian Polyphony and its Journeys from National Revival to Global Heritage
}

DOI:

10.1093/oxfordhb/9780199765034.013.017

\section{Document Version}

Accepted author manuscript

Link to publication record in Manchester Research Explorer

\section{Citation for published version (APA):}

Bithell, C. (2014). Georgian Polyphony and its Journeys from National Revival to Global Heritage. In The Oxford Handbook of Music Revival (pp. 573-597). Oxford University Press.

https://doi.org/10.1093/oxfordhb/9780199765034.013.017

\section{Published in:}

The Oxford Handbook of Music Revival

\section{Citing this paper}

Please note that where the full-text provided on Manchester Research Explorer is the Author Accepted Manuscript or Proof version this may differ from the final Published version. If citing, it is advised that you check and use the publisher's definitive version.

\section{General rights}

Copyright and moral rights for the publications made accessible in the Research Explorer are retained by the authors and/or other copyright owners and it is a condition of accessing publications that users recognise and abide by the legal requirements associated with these rights.

\section{Takedown policy}

If you believe that this document breaches copyright please refer to the University of Manchester's Takedown Procedures [http://man.ac.uk/04Y6Bo] or contact uml.scholarlycommunications@manchester.ac.uk providing relevant details, so we can investigate your claim.

\section{OPEN ACCESS}




\title{
Chapter 26
}

\section{Georgian Polyphony and its Journeys from National Revival to Global Heritage}

\author{
Caroline Bithell
}

University of Manchester, UK

NOTE: This is a post-print (Author's Accepted Manuscript) for:

Georgian Polyphony and Its Journeys from National Revival to Global Heritage.' In The Oxford Handbook of Music Revival, ed. Caroline Bithell and Juniper Hill, pp. 573-597. New York: Oxford University Press, 2014.

Situated in the Caucasus at the crossroads of Europe and Asia, Georgia has often been portrayed as a polyphonic island in a sea of homophony and (together with neighboring Armenia) an island of Christianity in the Islamic world. The iconic status of vocal polyphony in Georgia itself, where it is typically represented as the ultimate expression of both national character and regional identity, has been reinforced by outside recognition. Marius Schneider (1940) followed Siegfried Nadel (1933) in proposing that Georgia might be considered the cradle of European polyphony and its ancient singing traditions direct precursors of medieval art polyphony. Igor Stravinsky spoke of Georgian folk polyphony as "a wonderful treasure that can give for performance more than all the attainments of new music" (Levin 1989: 5), while Izaly Zemtsovsky has dubbed Georgia "the Treasure Island of Traditional Polyphony" on account of the remarkable diversity of forms and styles concentrated in such a compact territory (Zemtsovsky 2010: 253). In 1977, the song "Chakrulo"—an elaborate table song 
from Kakheti in eastern Georgia-was included on the Golden Record sent into space on the Voyager spacecraft, and in 2001 Georgian Polyphonic Singing featured in UNESCO's first Proclamation of Masterpieces of the Oral and Intangible Heritage of Humanity. ${ }^{1}$

Like cultural icons in many other parts of the world, Georgian polyphony has been subject to cycles of revival that have coincided with different historical moments. In this chapter, a selective review of the changing fortunes of folk polyphony during the periods of Russian and Soviet occupation in the nineteenth and twentieth centuries and of the revivalist initiatives to which these developments gave rise forms the foundation for my more detailed discussion of the most recent wave that gathered force after Georgia's achievement of independence from the Soviet Union in 1991. This latest wave was marked most visibly by the proliferation of traditional-style performance ensembles as well as renewed scholarly activity with the capital, Tbilisi, serving as the epicenter. At the same time, increasing numbers of Georgian choirs - most of them made up entirely of non-Georgians - were to be found outside Georgia, with the greatest concentration in Britain, North America, Australia, and France. Georgian songs also began to feature in the more eclectic repertoires of many community choirs in these same countries. These networks of (mostly amateur) enthusiasts have helped facilitate the ever more frequent overseas concert and workshop tours undertaken by Georgian ensembles. Meanwhile, growing numbers of converts have made the pilgrimage to remote Caucasian villages to study more intensively with revered songmasters. These trends took on more complex dimensions following the 2001 UNESCO declaration, with investment and promotion now coming from several different sources, both internal and external. In the post-Soviet era, polyphony has been made to do important cultural work as part of Georgia's reimagining and repositioning of itself in the global arena.

The choice of terminology used to describe processes of cultural renewal is often subject to debate. Georgian scholars employ the term "revival," albeit with reservations; the 
terms "restoration" and "renaissance" are also used. Many are keen to emphasize that Georgian polyphony has never literally died out and that the post-Soviet revival impulse is not new but provides continuity with earlier waves of revival. Others argue that since contemporary performance practices involve the recontextualization and transformation of what is considered "primary" or "authentic" folklore they cannot be seen as a literal revival of past practice. "Revival" is less problematically applied to liturgical chant, which was formally suppressed during the Soviet period. My purpose here is not to ascertain whether or not the Georgian case constitutes a revival in any absolute sense but rather to identify revival-like features, to probe more deeply into the question of what exactly has been revived, to examine the mechanisms by which such revival has taken place, and to consider related issues of recontextualization and transformation as productive areas of study in their own right.

More particularly, I wish to view foreign involvement in Georgian singing through the lens of revival and to examine the internationalization of Georgian folk polyphony as a postrevival process. In models of cultural imperialism, the act of embracing elements of another culture's heritage is all too often represented in wholly negative terms as a wanton taking of any object of one's desire and a cannibalistic consumption of a powerless "other," as suggested by titles such as Cannibal Culture: Art, Appropriation, and the Commodification of Difference (Root 1996). The Georgian case prompts me to challenge such assumptions by suggesting that the phenomenon of non-native, amateur singers becoming participants in the musical traditions of another culture might be viewed as an extension of internal revival processes, especially when increasing numbers of culture-bearers are apparently eager to share their heritage with outsiders. A revival often involves the translation of musical practices, functions, and meanings from highly localized, usually rural contexts, where music making is a natural part of ordinary people's day-to-day lives, to translocal, often urban environments where selected genres are adapted by a new constituency of music makers- 
typically younger, more highly educated, and with a consciously articulated agenda - who may themselves be considered outsiders to the original tradition. Georgian scholars represent this distinction in terms of primary and secondary folklore, or folklore's first and second existence. So-called primary ensembles are based in villages and operate as an integral part of daily life and ritual cycles, while secondary ensembles operate in professional or semiprofessional contexts, mostly in urban areas, presenting songs from a variety of regions on stage. From this perspective, the new lease of life enjoyed by Georgian polyphony in the wider world might be represented as a third existence of folklore, with the shift to non-native singers being viewed as just one more stage in a series of appropriations and relocations spreading out in concentric circles from the original nucleus. At the same time, it is in this shift that the transformative impacts of revival processes are most starkly revealed.

The drama that is to be played out in the pages that follow takes place against a broader backdrop populated with concepts of global cultural flows, imagined communities, transnational networks, and new world orders. Its actors inhabit a landscape where borders, both physical and metaphoric, have become increasingly permeable, where once primordial identities are now seen as fluid and negotiable, where lifestyles are—for some, at least—as much a matter of choice as of destiny, and where the future is still to be claimed.

$<1>$ Polyphonic Singing Traditions in Georgia: A Brief Overview

Georgia's polyphonic repertoire is immensely varied with respect to both song genres and regional styles. ${ }^{2}$ Lullabies, laments, healing songs, wedding songs, love songs, work songs, riding songs, dance songs, historical songs, table songs, joking songs, and ritual songs-some dating back to pre-Christian times — can all be found in multi-part arrangements. ${ }^{3}$ The majority of these are in three parts, with each of the two upper lines performed by a single 
voice, allowing for free variation and improvisation. Georgian ethnomusicologists map the country into fifteen regional "singing dialects" whose styles range from the three-part songs of Svaneti, where the voices are arranged in vertical block chords (designated "chordal units polyphony" in Georgian writings), to the spectacular table songs of Kakheti where two soloists weave elaborate melismatic lines over a bass drone ("drone polyphony"), to the boisterous and spirited songs of Guria featuring three or four independent lines that may undergo extensive embellishment ("contrastive-linear polyphony"). The Gurian tradition is further distinguished by the yodel-style krimanchuli voice.

A rich heritage of polyphonic church chant, again for three voices, crystallized in the medieval period. Three regional styles have been preserved through oral tradition and the efforts of the late-nineteenth-century preservation movement: these are represented by the Kartl-Kakhetian school in eastern Georgia and the monastery schools of Gelati and Shemokmedi in western Georgia. Chanting operated as a professional activity, set apart from the world of folk song by its formalized teaching methods. Accomplished chanters were appointed to direct church choirs, and master chanters would memorize all three voice parts for thousands of chants, aided by a system of medieval neumes. As the monasteries and their schools were put under increasing pressure under foreign occupation, some master chanters set up private schools in their own homes where students would pay to attend lessons. In some regions, the graduates of the chant schools were also instrumental in the refinement of secular genres.

Part of the appeal of Georgia's polyphonic heritage to a Western ear lies in its preservation of seemingly ancient modal styles with their distinctive tunings and a penchant for procedures that have long been proscribed in Western European music-so-called dissonances, parallel fifths, tritones, and other forbidden pleasures. (Georgian musicologists do not distinguish between consonance and dissonance.) The fifth or fourth, rather than the 
octave, forms the basis of Georgian scales, and the ubiquitous 1-4-5 chord (referred to in some early-twentieth-century writings as a trichord or "Georgian triad" and now most often labelled a fourth-fifth chord) acts as the most characteristic indicator of the Georgian "sound." The unusual harmonic sequences that bear no relation to procedures found in Western functional harmony, together with the untempered but finely tuned intervals of what some scholars identify as the "Georgian scale," also lie at the heart of the national mission to safeguard a sound world that is seen to be authentically and uniquely Georgian.

$<1>$ Cycles of Revival

The ways in which musical practice and scholarship in Georgia have evolved in recent times have inevitably been influenced by changes in the country's geopolitical orientation. Having voluntarily become a protectorate of tsarist Russia in 1783 in an attempt to escape centurieslong pressure from Persia and the Ottoman Empire, Georgia found its trust betrayed when in 1801 Alexander I abolished the Georgian monarchy and the whole territory was gradually incorporated into the Russian Empire. Following the October Revolution of 1917, the country enjoyed a brief period of independence as the democratic Republic of Georgia before falling to the Red Army in 1921 to become the Georgian Soviet Socialist Republic. In 1991 Georgia finally broke free of the crumbling Soviet regime, once again declaring itself an independent republic, and in 1999 became a member of the Council of Europe.

My purpose in the following sections is to highlight the main factors behind the revival impulses that emerged in these different historical periods and to outline the kinds of shifts and innovations that occurred with respect to the musical fabric, modes of transmission, and the infrastructures that supported musical production, preservation, and promotion. My 
particular interest here is in the way in which such trends can be brought into dialogue with the later adoption of Georgian polyphony by non-native singers.

$<2>$ Revivalist Trends under the Russian Empire

My retrospective begins with the revivalist initiatives aimed at protecting and promoting the national heritage that took shape during the years of Russian occupation. From around 1860, musical activity was closely aligned with the rise of the democratic revolutionary and national liberation movements, and the notion of revival was explicitly invoked by the patriotic writers of the day. The nation's “ancient" polyphonic songs were identified as a central component of the "pure" Georgian heritage that kept alive a glorious past uncontaminated by influences from more recent Islamic incursions. Promoting the practice of folk song and chant was also seen as a way of achieving national unity.

The latter half of the nineteenth century saw the staging of the first formal concerts of Georgian folk music, as well as the publication of the first essays and folksong collections. The Kartuli Khoro (Georgian Choir), founded by Lado (Vladimer) Aghniashvili in 1885, was the first professional "ethnographic" choir. Aghniashvili's aim was to collect and perform songs from the different regions as a way of acquainting the populace with their national heritage. Songs were transcribed from traditional singers and then re-taught to the choir, and a professional Czech musician, Iozef Ratil, was brought to Georgia expressly to serve as conductor. The choir's inaugural performance in Tbilisi in 1886 went down in history as the first concert of Georgian folk music to be staged in the so-called modern manner. Yet while the Khoro's appearance was hailed by some as a triumphant celebration of the nation's heritage, for others it was the beginning of an inevitable process of homogenization as regional nuances were lost. In this sense the Khoro has been seen as heralding the 
displacement of authentic folklore by folklorism and the transformation of traditional folk singers into "receiver[s] of a ready-made folklore" (Tsurtsumia 2010: 261). It also represented what was for purists a regrettable imposition of Western European aesthetic values and practices. In particular, Ratil would later be criticized by Dimitri Araqishvili (the "father" of Georgian ethnomusicology) for "spoiling" and "contaminating" Georgian songs by over-use of the Western harmonic interval of a third, which he characterizes on one occasion as "the trivial third" (Tsitsishvili 2010: 101).

Liturgical chant attracted revivalist attention of a different kind. The independent Georgian patriarchate had been abolished in 1811 and Georgian singing in the churches was suppressed as Georgian Orthodoxy was replaced by Russian Orthodoxy, with Old Church Slavonic taking over as the new language of the liturgy. Although the teaching of chant continued in the private schools and homes of established families of chanters, the oral tradition of chanting was nonetheless in decline and this prompted the establishment, in 1860, of the Committee for the Revival of Georgian Church Singing (sometimes translated as Committee for the Restoration of Georgian Chant, or Council for the Resurrection of Georgian Church Song — the implied equivalence of "revival," "restoration," and "resurrection" is noteworthy). The committee's main goal was to formalize the transmission process and make the chants accessible to a wider constituency of practitioners. Dedicated transcribers set to work, collaborating with individuals who still preserved sizeable proportions of the material in their memories. Between the 1880s and the 1920s, thousands of chants were painstakingly rendered into Western staff notation. Among the most prolific transcribers was the opera singer Pilimon Koridze (1835-1911), who devoted the last thirty years of his life to transcribing nearly five thousand chants; fifteen hundred copies of his first book of transcriptions were printed in $1895 .^{4}$ 
The dawn of the twentieth century saw the beginning of recording activity. The British Gramophone Company opened an office in Tbilisi in 1901 and assembled a substantial collection of folk song recordings before it was forced to cease operations with the outbreak of the First World War. Musicologist and composer Dimitri Araqishvili recorded over five hundred songs in different parts of Georgia, later publishing transcriptions based on his collection. Collections held at the Berlin Phonogram Archive include thirty-eight wax cylinders recorded by Adolf Dirr in Georgia between 1909 and 1913 and seventy-one cylinders recorded by George Schünemann in German prison camps between 1915 and 1918 . Like the chant transcriptions, these and other early recordings — not all prompted by revivalist impulses but representing invaluable records of the pre-Soviet sound world-would later constitute a precious resource not only for scholars but also for the new generation of performing ensembles that would proliferate in the post-Soviet period, with many being remastered and released in new compilations as part of the explosion of activity that followed the UNESCO declaration (see discography).

$<2>$ Musical Transformations and Cycles of Renewal in the Soviet Era

The few years of Georgian independence between the Russian Revolution of 1917 and the Bolshevik takeover of 1921 saw a flurry of activity as Tbilisi blossomed into a vibrant cosmopolitan city that attracted artists and intellectuals from other less prosperous and less tolerant parts of the former Russian Empire (see further Ninoshvili 2010: 55-58). If this golden age was short-lived, it served nonetheless to put in place some of the structures that would support musical scholarship in the Soviet years. These included Tbilisi Conservatoire and Tbilisi State University, established in 1917 and 1918 respectively. 
Under the new regime, music making had to adapt to Soviet ideology and to a stateimposed system that supported particular kinds of approved activity while pushing other practices underground. Singing was nonetheless encouraged as a professional art, with substantial support also extended to amateur musical collectives. Houses of Culture were established in towns and villages, expert singers and trained conductors were employed to set up performing ensembles, and the latter were then encouraged to compete in the national festivals and Olympiads that served as showcases for a new brand of "modernized folklore." Ensembles increased in size as different district authorities strove to outshine one another, with some of the largest choral collectives numbering a hundred voices or more.

These massed choirs, like the more polished, professional performing ensembles epitomized by the State Ensemble of Song and Dance (founded in 1936), necessitated changes in performance practice for pragmatic as well as ideological reasons. The two upper melodic lines, traditionally executed by a single voice, were now sung in unison by large forces. This called for standardized arrangements that left no scope for improvisation. Highly choreographed versions of carefully selected songs were further fixed through their dissemination via state radio and television. These and other non-traditional practicesamong them the use of conductors, the deliberate teaching of individual song parts, and the addition of instrumental accompaniment with traditional folk instruments now tuned chromatically_were resented by many not only as Soviet impositions but also as symptoms of further Europeanization. Viewed in a different light, these inter-related processes of standardization and Westernization, combined with the new pedagogic methods, might be seen to have paved the way for the later transfer of Georgian repertoire to non-native choirs.

The post-Stalin era of the 1950 s to 1980 s saw a partial return to more traditional, smaller ensembles, some of which specialized in songs from a single region. The early trailblazers of this new style were Shvidkatsa and Gordela (established in 1957 and 1961 
respectively), followed by Rustavi (1968). In retrospect, these formations are seen to occupy a transitional position. On one hand, they adopted methods viewed at the time as progressive: members of Gordela, for instance, studied archival recordings, undertook fieldtrips, and worked with mastersingers, with the joint aim of cultivating what they considered to be a more authentic style and searching out lesser-known variants of songs. In other respects, they continued to reinforce the so-called academic style of performance of the larger Soviet choirs (for example, employing trained voices and adding dynamic coloration). The retention of certain aspects of performance practice otherwise identified with state control was also to some extent a conscious choice, understood as a necessary compromise when the objective was to cultivate new audiences overseas (see Gabisonia 2007).

Questions of national identity and authenticity came to the fore once more in the 1980s as the Soviet Union began to fail. Two leading figures in the wave of revival that bridged the pre- and post-independence years were Edisher Garakanidze and Malkhaz Erkvanidze, both accomplished singers and energetic researchers associated with the Department of Georgian Traditional Music at Tbilisi State Conservatoire. Both were also to become popular teachers of Georgian songs in Britain and elsewhere. Their careers therefore offer valuable insights into the motivations and methods of native practitioners who teach their songs to outsiders and the way in which this undertaking relates to their revivalist endeavors within their own society.

Garakanidze is generally acknowledged as having initiated a new return-to-the-roots by shifting the focus back to the villages that provided the primary habitat for folk music. He undertook regular fieldwork expeditions to remote parts of the country, in the process amassing a wealth of knowledge relating to indigenous life ways and beliefs as well as expertise in interpreting the different styles of song that he recorded and documented so meticulously. Rusudan Tsurtsumia (director of the conservatoire's International Research 
Center for Traditional Polyphony) writes of how he "tried to rear a 'folklore subject' in his own self, to awaken genetic memory" by spending long periods living "in village conditions" (Tsurtsumia 2010: 261). Garakanidze's recognition of the difficulties of sustaining so-called primary folklore in its natural environment led him to found the all-male, Tbilisi-based ensemble Mtiebi in 1980, followed in 1986 by the female ensemble Mzetamze, whose members were fellow ethnomusicologists trained at the conservatoire. In Britain, Garakanidze is revered for having first introduced Georgian songs to the amateur singing community, with the help of his colleague Joseph Jordania, and the thriving network of Georgian choirs there is an important part of his legacy (see below).

Other new ensembles came together as part of the movement to reintroduce the practice of Orthodox chant, live chanting in the churches having been suppressed for almost seventy years. Malkhaz Erkvanidze is credited with having led this latest chant revival on both practical and academic fronts; his contribution to Georgian scholarship includes several volumes of chant transcriptions (under the title Georgian Church Chant) that serve as a rich resource for researchers and singers alike. In 1988 Erkvanidze founded the Anchiskhati Choir, which began by chanting at the Anchiskhati Church (Tbilisi's oldest Orthodox church dating back to the sixth century) and went on to become a leading exponent of Georgian polyphony on the world stage. Later, in 2006, he formed Sakhioba (fig. 1), an ensemble made up of younger singers (some of them students at Tbilisi Theological Academy and Seminary) who describe themselves as "members of Georgia's newest generation of revivalist musicians" (http://www.sakhioba.ge/eng). Like other contemporary ensembles such as Zedashe, Shavnabada, and Sathanao, Sakhioba again assumed an interesting bridging role as it directed its energies to the continued promotion of Georgian folksong and chant both at home and abroad. 


\section{[INSERT COMPUTER ICON FOR WEB FIGURE 1 HERE]}

$<2>$ Independence, UNESCO, and the Turn to the West

The collapse of the Soviet Union gave Georgian scholars and artists, in principle, greater freedom to pursue contacts with colleagues and audiences in the West. Such aspirations were, however, severely hampered by the profound economic and political crises into which the country was plunged after the initial spell of post-independence euphoria. Military conflicts, uncontrolled banditry, mafia-style corruption, and economic instability blighted the 1990s, with fuel shortages and widespread power outages seriously restricting professional as well as domestic life. It was only towards the end of the decade that Georgian ethnomusicologists were finally able to resume fieldwork expeditions, some being funded by the Open Society Georgia Foundation (part of George Soros' Open Society Institute). ${ }^{5}$ In 1998 and 2000, the conservatoire also hosted conferences on "Problems of Folk Polyphony" and "Problems of Polyphony in Sacred and Secular Music" (see Tsurtsumia et al. 2000 and 2001), the second of these again supported by the Soros Foundation. These events picked up the thread of an earlier series of international conferences on folk polyphony that had taken place in Georgia in 1984,1986 , and 1988 .

The real turning point in the country's political fortunes came with the Rose Revolution of 2003 that unseated President Eduard Shevardnadze in favor of the young, USeducated Mikheil Saakashvili. Alongside his many projects aimed at improving Georgia's economic prospects and attempting to bolster national security by realigning the country with Western democracies, Saakashvili would assign significant sums to the promotion of Georgia's cultural riches - an investment that was, to begin with, a requirement of the 
contract entered into by the state in conjunction with the 2001 UNESCO proclamation of Georgian polyphony as a Masterpiece of the Oral and Intangible Heritage of Humanity.

Since in order to secure UNESCO support a case has to be made that the heritage in question is endangered, the accompanying plan of action is almost de facto framed in revivalist terms. In Georgia, UNESCO recognition prompted a surge of revivalist activity, including the preparation of new publications, audio-visual materials, and websites. New performing ensembles and festivals also appeared. The conservatoire launched a fresh series of biennial symposia that built on the earlier conference model but attracted a far wider range of delegates from overseas. ${ }^{6}$ The First International Symposium on Traditional Polyphony, held in 2002 and organized in partnership with the non-governmental International Center for Georgian Folk Song, led directly to the establishment, in 2003, of the conservatoire's International Research Center for Traditional Polyphony as part of a major UNESCO-funded project entitled "Safeguarding and Promotion of Georgian Traditional Polyphony."7 Running from July 2003 to November 2006, the project had the explicit aim of "facilitat[ing] the safeguarding of Georgian polyphony through fostering its inter-generational transmission and its collection and inventorying" (UNESCO 2008: 1). The Research Center was equipped with state-of-the-art audio-visual and computer equipment that allowed it to embark on an ambitious plan to digitize its archival holdings and create a database, and a new bilingual website (Georgian/English) was designed with sufficient capacity for these and other materials - including the full published proceedings of the symposia from 2002 onwards - to be made available online (see http://www.polyphony.ge).

Another central component of the program (described in the post-project report as a "key sustainable output") was the founding of seven regional Youth Folk Song Centers. The buildings that housed the centers were provided free of charge by the local municipalities and then equipped with teaching materials, audio-cassettes, CDs, and sheet-music prepared by the 
International Center for Georgian Folk Song (hereafter ICGFS). The report emphasizes the use of new media and technology as an important means of making traditional material appealing to a younger generation. The ICGFS also ran seminars on teaching methods and use of the equipment for the performers/teachers attached to the centers. In each hub, a group of between ten and fifteen students received training from older songmasters in the singing style and song repertoire of that region; many of these young "graduates" then went on to form ensembles of their own.

Following the initial period of UNESCO investment, four of the centers continued to operate with the help of local sponsors, and an additional School of Krimanchuli was opened in Guria, funded jointly by the ICGFS and the Georgian Patriarchate. The terms used to record these developments offer interesting perspectives on the question of what might be revived in addition to the music itself: "The notions of social responsibility and engagement in the private sector and the religious authorities were values and practices discouraged during the 70 years of communist regime in the country, and are now being revived and motivated by the international and national recognition of local cultural value" (UNESCO 2008: 2). Continuation funding was also made available by the new government. In 2006, a budget of 1.5 million lari (USD 867,000) was set aside for cultural development, and Saakashvili launched his "President's Support for Folklore" program with the donation of 2,500 costumes to members of regional folk ensembles across the country (Ninoshvili 2010: 3). Among other presidential initiatives were an award of 70,000 lari to the Folklore State Center of Georgia to resurrect the folk Olympiad of the Soviet years, now rebranded as a National Folklore Exhibition-Festival, and the nomination of Anzor Erkomaishvili (founder of the multi-awardwinning Rustavi Choir and director of the ICGFS) to co-ordinate a national project to integrate Georgian polyphony into the school curriculum.

Working alongside the International Research Center for Traditional Polyphony, the 
ICGFS issued a number of publications aimed at "specialists and enthusiasts of Georgian folk song," including anthologies of musical notation, monographs on folk singers and chanters, and CDs featuring both archival and contemporary recordings. A series of teach-yourselfstyle resources was launched with Let Us Study Georgian Folk Songs: Gurian Songs, coedited by David Shugliashvili and Malkhaz Erkvanidze and issued to coincide with the First International Festival of Georgian Folk Song, Chven Mshvidoba, held in Guria in 2004. A second set, Teach Yourself Georgian Folk Songs: Megrelian Songs, again included a songbook with musical transcriptions and lyrics, supported by CDs on which the songs were presented with each part sung separately as well as in ensemble. Although these materials were intended primarily as resources to help cultivate a new generation of Georgian singers, foreign enthusiasts were also able to acquire copies during visits to Georgia or via online platforms.

While the programs supported by UNESCO were aimed first and foremost at revitalizing musical activity at national level, the accompanying commitment to disseminate the heritage to the wider global community, together with UNESCO's more general redefinition of regional and national traditions as world heritage, resonated with Georgia's post-independence desire to forge new alliances with Europe and America. At the same time, evidence of the increased recognition accorded to Georgian polyphony by the international community helped to further raise its status nationally.

$<1>$ The Internationalization of Georgian Polyphony: Foreign Choirs and Networks By the time of these latest developments, the phenomenon of foreigners performing Georgian songs was already well established, as evidenced by the selection of visiting choirs and ensembles that appeared at the First International Symposium on Traditional Polyphony in 
2002 as part of the program of concerts staged alongside the academic panels. These included Gorani and Golden Fleece from Australia, Kavkasia from the United States, Darbazi from Canada, Maspindzeli from Britain, Irinola from France, and Geinoh Yamashirogumi from Japan. Of these, the majority had been established in the mid-1990s, although Geinoh Yamashirogumi - the first known foreign ensemble to adopt Georgian songs into its repertoire - had been active since 1974. A few of these and other formations that have appeared outside Georgia do include Georgian emigrants; the trio Golden Fleece, for example, was established by ethnomusicologists Joseph Jordania and Nino Tsitsishvili following their relocation to Melbourne in 1995, with Joseph also providing the Georgian expertise for Gorani, a larger Melbourne-based choir devoted to Georgian and Bulgarian songs (fig. 2). Most foreign ensembles, however, are made up of amateur singers with no ethnic connection to Georgia.

\section{[INSERT FIGURE 2 HERE]}

\section{[INSERT COMPUTER ICON FOR WEB FIGURE 2 HERE]}

From the foregoing survey of the trajectory of Georgian polyphony within Georgia itself, we may note a series of trends and developments that helped pave the path by which these foreign exponents made their entry: (i) the accumulation of archival recordings, latterly reassembled, remastered, and rereleased, with some being made more widely available through online databases; (ii) the existence of historical transcriptions informed by an original desire to make the material more accessible; (iii) the more recent addition of teaching materials using up-to-date media and methods and designed specifically for new recruits who had not grown up in the tradition; (iv) the presence of pioneering researcher-practitioners like Edisher Garakanidze and Malkhaz Erkvanidze who had embraced the task of revival as their life's work and had already successfully initiated a new cohort of practitioners, mainly in Tbilisi; (v) the presence of older village songmasters who again were experienced in 
transmitting their art to the younger generation; (vi) the fact that the repertoire itself had already been subject to processes of standardization and Westernization as it was adapted for performance by large choirs and accommodated to Soviet conventions and the assumed tastes of European audiences; (vii) the renewed post-independence desire to bring Georgia's cultural heritage to the attention of an international (especially Western) audience, subsequently reinforced by the strategies and discourses promoted by UNESCO; and (viii) a new wave of traditional-style ensembles whose well-trained and more cosmopolitan-minded members were keen to establish concrete links with musical networks in the West and whose recordings and filmed performances could easily be found on the Internet.

These national-level developments met with other trends in the places to which Georgian songs would find their way. Most significant was the appearance of community choirs and world music choirs whose repertoire consisted of an eclectic mix of multipart songs from many different parts of the world, a phenomenon that was especially prominent in the United Kingdom and parts of the United States. The singers associated with these choirs already had a taste for radically different kinds of music and they were accustomed to learning by ear and singing in languages that were not their mother tongue. In the UK, the community choir scene-itself part of a broader movement that crystallized around the Natural Voice Practitioners' Network-was further supported by a culture of weekend workshops and by initiatives such as the biennial Giving Voice Festival that brought together artists from all over the world for a program of performances and intensive masterclasses, the latter typically spread over several days.

For the next part of my discussion, I step back in time to uncover the more singular stories of how some of the foreign choirs and ensembles devoted exclusively to Georgian music came into being. In the process, I seek to probe the motivations of the different stakeholders and the benefits that they have each derived from these acts of cultural exchange, 
and to identify further points of articulation between these developments and revivalist trends within Georgia itself. Particular attention is paid to those who have acted as intermediaries and to the methods of teaching and learning that have proved most effective.

$<2>$ Becoming an Ambassador for Someone Else's Culture: Converts and Intermediaries

The careers of fellow Americans Carl Linich and Frank Kane offer interesting insights into the trajectories of non-Georgians who have dedicated themselves to Georgian music following an initial life-changing encounter and have subsequently been responsible for the induction of large numbers of Westerners into the art of Georgian singing. The short accounts that follow serve to shed light on (i) the manner in which a personal relationship with Georgian music has developed; (ii) the process of refining teaching methods for relatively inexperienced singers in the West; (iii) the way in which certain properties of Georgian singing have been linked with broader principles; and (iv) the phenomenon whereby deepening involvement with the music has led to more extensive, long-term involvement in Georgian affairs.

Carl Linich began his Georgian singing journey as a member of the Kartuli Ensemble (see below). In 1994 he joined forces with fellow singers Alan Gasser and Stuart Gelzer to form Kavkasia. Motivated by the desire to go deeper into the music in a way that was not practicable for a sizeable amateur group that rehearsed relatively infrequently, their adoption of the trio format also allowed them to return to the more authentic practice of having one voice to each part, leaving greater scope for improvisation. In 1995 the friends travelled together to Georgia "to do our homework" and "to be at the source" (Carl Linich, interview, October 8, 2010, Tbilisi). The five months spent studying the language as well as the music was, for Carl, "a turning point . . . in my life.” In the United States, they had learnt songs from 
transcriptions and recordings but now they were able to take lessons with none other than Anzor Erkomaishvili. Learning by ear from someone so well versed in the tradition gave them a clearer understanding of the ways in which Georgian scales differed from the Western tempered scale and, upon returning home, they spent "countless hours . . really working on these very fine nuances of tuning." Old archival recordings from the early Soviet and preSoviet years also provided valuable models, just as they did for the new generation of revivalist singers in Georgia itself. ${ }^{8}$

Carl soon returned to Georgia, which became his main home for the next ten years, and in 2001 he founded Okros Stumrebi (Golden Guests), a choir for expatriates of different nationalities living in Tbilisi. He had already begun teaching Georgian songs to a wider network of singers back in the USA when, in 1999, he was invited to lead workshops for the Vermont-based association Village Harmony. He subsequently served as the point of introduction for Village Harmony's first summer camps in Georgia, which took the form of singing tours combining study and performance. In 2007, in collaboration with Georgian colleague Maia Kachkachishvili, he launched his own "songmaster tours," designed for smaller groups to study intensively with teachers drawn from the older generation of village singers. Carl also went on to collaborate with Tbilisi State Conservatoire, the Folklore State Center of Georgia, and the International Center for Georgian Folksong on a number of publications, including the teach-yourself anthologies of Gurian and Megrelian songs referred to earlier. Having been awarded a Silver Medal by the Georgian Ministry of Culture in 1997 in recognition of his profound knowledge of Georgian folk music and his achievements in promoting Georgian culture abroad, in 2009 he became a recipient of the prestigious President's Order of Merit Award. ${ }^{9}$

Initially, Carl was following in the footsteps of Frank Kane, likewise a recipient of the Silver Medal. Frank first travelled to Georgia in 1984 with the Yale Russian Chorus. This 
experience inspired him to launch the Kartuli Ensemble, dedicated entirely to Georgian songs, the following year. In 1988 he moved to Paris to study Georgian at the Institute of Oriental Languages and sang with a group made up largely of Georgian emigrants before founding the all-male ensemble Marani in 1993, followed by Irinola, a female ensemble, in 1997. Under the auspices of the Marani Association he established a program of cultural exchange, as part of which he invited songmasters from different regions of Georgia to lead workshops in Paris (paradoxically, this was at a time when, because of the troubled political and economic situation, they had very few opportunities to teach in Georgia itself). Outside France, Frank has built a reputation as a popular workshop leader in Britain, Ireland, Germany, Austria, Switzerland, the USA, and Canada.

Frank's case is especially interesting in respect of the original methodology that he has developed as a means of helping non-Georgians achieve a more authentic sound. His conviction that simply listening and repeating was not enough, since what Western students hear is "put through the filter of their own prior experience and frame of reference" (Kane 2003: 558), led him to experiment with exercises designed to help his French students locate the non-tempered intervals used in Georgia and improve their perception of harmonics and vibration. Aided by his knowledge of Tai Chi, Hatha Yoga, and Alexander Technique, he also worked with what he terms the "physical disposition and intention" of the singers. Careful study of the way in which Georgian singers stand, open their mouths, move their jaws, and breathe, for example, prompted a series of revelations about how such factors were implicated in vocal production and timbre. "By gaining a better understanding of how Georgian singers produce their sound," he concluded, "non-Georgian singers are no longer simply imitating a sound, they are imitating the physical gestures and intentions which form this sound" (ibid: 561). Frank's deepening relationship with Georgian polyphony also took on more universal dimensions with his conviction that the vibratory fields produced in the body by this kind of 
singing had powerful healing potential. All of these insights informed his proposal that "Georgian singing, as a point of entry to gain a knowledge of the voice, vibration, and harmony singing, has a pan-human dimension and, like hatha yoga or tai chi, is a practice that can and should be shared with and available to all humanity" (pers. comm., February 28, 2012)..$^{10}$

$<2>$ Georgian Singing in Britain and Ireland: The Legacy of Edisher Garakanidze

The case of Georgian singing in Britain and Ireland offers further insights into the manner in which affinity groups and practical networks develop in places far removed from the original source. In this instance, an almost chance beginning led to quite momentous consequences as dedicated Georgian choirs multiplied and ever-greater numbers of ordinary singers with no prior knowledge of Georgia were drawn into the wider, transnational Georgian-singing community. The journey began in 1994 when, on the recommendation of a recent visitor to Tbilisi, Edisher Garakanidze and Joseph Jordania were invited to Cardiff by the Centre for Performance Research (CPR) and tasked with preparing an ad hoc choir to perform a set of Georgian songs at the closing feast of a weeklong conference on the theme "Performance, Food, and Cookery." For many of the participants, this was the beginning of a lifelong passion for Georgian culture. With the help of singer and composer Helen Chadwick, who would later form the London Georgian choir, Edisher returned to Britain several times before his untimely death in a road accident in 1998. In addition to leading further workshops for the CPR and other organizations, he worked with community choirs across the country, many of which were directed by singers who had been part of the original Cardiff choir, and also with theater companies and schools (fig. 3). In this way, he helped establish a common repertoire 
that would be consolidated by the posthumous publication of 99 Georgian Songs: A Collection of Traditional Folk, Church and Urban Songs from Georgia.

[INSERT FIGURE 3 HERE]

99 Georgian Songs was, in Edisher's words, intended as a workbook “for singers in the West who want to learn these songs, but want to know about the meaning, where the songs come from, singing style and so on” (quoted in Mills 2004: vi). In his introduction, Edisher spoke of workshop participants becoming "the co-owners of a culture that stems from the depth of centuries and millennia" (Garakanidze 2004: ix) - a notion that is indicative of the ecumenical mindset he adopted and his secure conviction that in sharing one's heritage one is not left deprived. Edisher had his own style of teaching that enabled his British students to achieve a more Georgian sound. Helen Chadwick recalls being especially struck by how the stories he told to set the songs in context would enable workshop participants to imagine themselves in the settings he described, with the result that "the song would fly in a different way ... as opposed to it just being some nice harmonies and a few words_ _ giving a reason to sing" (interview, February 4, 2008, London). Edisher deliberately made certain musical and textual adjustments in order to make the material more accessible for beginners. The Georgian language with its predilection for complex consonant clusters initially poses a considerable challenge for foreign learners. Edisher's solution was to "select songs with as little text as possible" and to "deliberately decrease the number of consonants" (for example, rendering "ganbrtsqinvebuli" as "gatsinebuli"), with the aim of allowing singers to focus their attention primarily on the music and so make more rapid progress before returning later to refine their pronunciation (Garakanidze 2004: xv). Musical arrangements also underwent a degree of standardization for reasons already described. Making such compromises was in keeping with Edisher's categorization of the "authentic" rural performance style as "a higher level of learning which is by no means compulsory for all of those interested in Georgian music." 
Achieving this higher level "involves listening to authentic recordings, travelling to Georgian villages in different regions, and establishing personal contact with traditional singers"path already taken, he adds, by some Western singers such as Helen Chadwick and the members of Kavkasia (ibid.: xvi). Since Edisher wrote these words, many more Georgiansinging converts from Britain, North America, Australia, and different parts of Europe have deepened their knowledge and practice in precisely these ways.

For Edisher's many British friends, the shock of his sudden loss was combined with an urgent sense of responsibility to honor the gift of the songs he had shared by continuing his work. The Georgian Harmony Association was formed to act as a hub for disseminating information about workshops, concert tours, and other Georgian cultural events in the UK; this would later be complemented by the Northern Georgian Society. Helen Chadwick formed the London choir, Songs of the Caucasus (precursor to Maspindzeli), initially as a means of raising funds for the medical care needed by Edisher's son, the sole family member to have survived the accident. ${ }^{11}$ A decade into the twenty-first century, Georgian choirs in Britain and Ireland continued to multiply, joining those already established in places as far afield as Cambridge, Bristol, Aberystwyth, Leeds, Edinburgh, and the northern Scottish village of Findhorn. While the most recent recruits populating (and in some cases founding) these choirs had never met Edisher, they may nonetheless be seen as part of the legacy of his work. Meanwhile, the culture that he was instrumental in establishing was now well served by a new wave of visiting teachers from Georgia. Residential workshops in different parts of the UK fulfilled a bonding function for members of different choirs and continued to add to a shared repertoire. New choirs were also invited to Georgia to perform at the conservatoire's biennial symposium or at festivals such as Art Gene and Chveneburebi. [INSERT OWM SPEAKER ICON HERE - VIDEO TRACKS 26.01 AND 26.02] 
$<1>$ Georgia's Transnational Affinity Groups: From Attraction to Belonging

My discussion thus far has offered support for my initial proposal that we might conceptualize the activities of foreign practitioners as being in continuity with internal revival processes. Stories of the kind related above suggest a further subset of questions that warrant further probing. What does it mean to become part of someone else's revival or an ambassador for another culture? How does this articulate with notions of identity, ownership, and belonging? Is there a sense in which Georgian singers in Britain and elsewhere are involved in a local or personal revival of their own? What more might be said about mutual aspirations and rewards?

Many of those drawn to Georgian polyphony describe their first experience of hearing the music in terms of an epiphany. The prominence of intensely visceral imagery in the accounts I have gathered is striking: "It was like reaching into my heart and just grabbing me"-_It was like a key unlocking something in my chest"_- "It was like lightning going down and cutting my body up." This experience has typically initiated a quest for the keys to the mystery, which for some has evolved to become part of their life's purpose. The new insights that follow resonate in interesting ways with features that often appear as components of intentional revivals, especially those that originate as part of a social movement seeking to restore practices and meanings from the past that are viewed as more wholesome or authentic. Singers from overseas are often struck by the fact that so many songs still in circulation in Georgia have a specific function: in contrast to life at home, as one interviewee put it, "every human activity has a song attached to it." In the company of their new Georgian friends, they experience a heightened sense of communitas and conviviality that is reinforced in the context of the supra, an elaborate feast animated by eloquent toasts and impassioned singing. This sense of community extends to the singing networks they join or cultivate at home. The pre- 
Christian ritual music and dance traditions of Georgia's remote mountain regions hold a particular fascination for those already attracted to pagan survivals. At a strictly musical level, Georgian polyphony may relate to a bigger project of reviving older sounds and procedures similar to those that would have been the norm in Western Europe before the introduction of equal temperament and functional harmony. In the context of the natural voice and a cappella movements in the UK, USA, and Australia, with their conviction that "everyone can sing," Georgian songs are also part of a broader revival of oral tradition and this, too, can be framed as a desire to restore the ways things used to be. In these and other ways, Georgia- - whether real or imagined — offers a missing link to a lost past, a means of revitalizing the present, and a tantalizing glimpse of alternative futures that may still be within reach.

If such intimations lie at the root of many national revivals, their transformative potential takes on more complex dimensions in the context of lives lived elsewhere as they prompt more profound changes that reach to very heart of personal identities. Affective reactions of the kind cited above are often further described in terms of an uncanny sense of recognition or homecoming. Joan Mills (co-director of the Cardiff event where Edisher and Joseph made their British debut) recalls hearing British-Asian singer Sheila Chandra, whose solo albums include Weaving My Ancestors' Voices (1992), talking about how the voices of the ancestors can call you, even if they are not literally your own ancestors. This is what she herself felt, she explains, when she first heard Georgian songs (interview, July 24, 2005, Llanrhystud). Many of the American singers who find their way to Georgia, on the other hand, do have historical ancestors who came from different parts of Eastern Europe and so they may be in search of more tangible roots.

Mark Slobin, in elaborating his model of affinity groups as "charmed circles of likeminded music-makers drawn magnetically to a certain genre that creates strong expressive bonding" (1993: 98), has written of how "a choice to follow up an affinity leads to belonging" 
(ibid.: 56). This can be pragmatic as well as affective. The notion introduced at the start of this chapter - that the adoption of Georgian traditions by outsiders might be viewed as a "third existence" of folklore and a natural extension of a once inward-facing revival process - might help to elucidate Edisher's proposal that workshop participants become "coowners" of a culture. Most pertinent of all is the way in which the involvement of foreign practitioners has reached far beyond the simple fact of singing Georgian songs and paying lip service to the rhetoric of honoring Georgian culture. Many have entered into long-term relationships with the country and its people, some becoming part of an adoptive extended family based on personal friendships and others (like Carl Linich) playing a more direct part in national infrastructures and histories. These relationships bring a sense of responsibility. Members of the international Georgian-singing community have contributed financially as well as practically to a variety of cultural initiatives and humanitarian causes in Georgia, sometimes on the basis of a personal connection (leading, for example, to local collections for a struggling orphanage) and sometimes as part of a public response (for example, following the earthquake that struck Tbilisi in 2002). As Russian tanks rolled into Georgia in the summer of 2008, an international rallying call was immediately issued with the tagline "Let's Sing for Peace in Georgia." Members of choirs across the world sang Georgian songs in churches, town halls, and squares as a statement of solidarity and to raise public awareness of Georgia's plight, and donations were raised for the project of recovery and reconstruction. Those participating in singing holidays in Georgia also contribute, through the monies they pay for tuition and home stays, to the provision of modern amenities (such as indoor bathrooms) or the renovation of community buildings in under-resourced villages. This investment in turn allows local youth to glimpse the possibility of carving out a sustainable future without having to relocate to the city. Several young Americans who first visited Georgia to take part in a Village Harmony summer camp later returned on Fulbright 
scholarships and became fluent Georgian speakers. Others have relinquished their jobs back home and established a new life in Georgia.

Away from the capital, the concert stage, and the festival circuit, the task of revitalizing local practices in Georgia continues and here, too, visiting singers have been assigned a role. In 2011, a group of mainly British visitors found their way to Lakhushdi, a remote hamlet in the region of Svaneti (Upper Caucasus) that is home to extended families of accomplished musicians (fig. 4). It was the latter who issued the invitation for "sympathetic" foreign guests to help revitalize the feast of Limkheri by learning the pre-Christian songs and dances associated with it, their hope being that this would "send a powerful message to their own young people — children who have been born into a modern Georgia and a new generation of 'virtual' communications ... a clear message about the intrinsic value of roots, and about the spirit of a shared humanity" (http://www.braveheartgeorgia.org/). [INSERT OWM SPEAKER ICON HERE - VIDEO TRACKS 26.03 AND 26.04] Here, a message that originated with older family members in the local community was given added weight by the endorsement of visitors who could be viewed as representatives of the international community. The funds generated were used to start a co-operative that would oversee the development of a sustainable community enterprise; the first projects included filming previously undocumented rituals, launching a new local choir, and establishing a heritage center.

[INSERT FIGURE 4 HERE]

\section{[INSERT COMPUTER ICON FOR WEB FIGURE 4 HERE]}

If we wish to make a more direct comparison between the foreign affinity groups that have formed around Georgian singing and "classic" revival movements as analyzed by writers such as Tamara Livingston (1999) and Owe Ronström (1996), we may identify several characteristic ingredients. These include the key roles played by charismatic leaders or 
"burning souls," the circulation of publications and recordings, the establishment of formal networks and infrastructures, performance activity at different points on the scale from amateur to professional, a quest for authenticity balanced by processes of recontextualization and negotiation, the acquisition and display of ethnic artefacts (e.g. embroidered hats and waistcoats), and the adoption of cultural practices that mark one's membership of a recognizable subculture (e.g. holding supras). In many ways, as we have seen, overseas ensembles have also mirrored trends and refinements in performance practice, musical understanding, and research activity that have taken place in Georgia over a longer timescale. Larger choirs have given rise to smaller ensembles with one voice to a part, and individual singers have progressed to more intensive study of the Georgian system of pitches and intervals and the art of improvisation, sometimes undertaking their own fieldwork expeditions to Georgian villages.

Notably, foreign students of Georgian polyphony have at times had easier access to the older generation of songmasters than many of their Georgian counterparts, thanks in part to their superior mobility and spending power. Some have therefore approached closer to the inner sanctum of the tradition than young singers honing their craft in Tbilisi, where the music is already recontextualized and subject to a different kind of learning process, and this direct apprenticeship has added legitimacy to their efforts. The songmasters have been overjoyed to find such ardent acolytes with whom they can share a lifetime of knowledge in an age when-UNESCO and presidential promotional programs notwithstanding - the interest shown by young Georgians in their own heritage has undoubtedly diminished. The growing numbers of foreigners who have made their way to Georgian villages or arranged for the songmasters to travel abroad have also helped fill a void left by the dismantling of the old Soviet infrastructures by providing these aging singers with a new source of livelihood. 
These affinity groups may, perhaps, be viewed in terms of a sympathetic diaspora. In an age where discourses of multiculturalism have given way to notions of the transcultural (Hannerz 1996) and postethnic (Hollinger 2005), diasporas - like national belonging — can be elective as well as literal. The path taken by outsiders who have penetrated to the heart of Georgian polyphony might be conceived as conventional diaspora-formation in reverse. For many, Georgia becomes a surrogate motherland and, for others, quite literally a second home. At different points in this unfolding drama, the desires and responses of foreign extras meet with the aspirations of the Georgian lead actors in an exchange that is directed and produced by cosmopolitan culture-brokers who bridge the insider-outsider divide. Through this process, ostensible outsiders with no genetic, territorial, or otherwise logical connection to Georgia become part of a quasi-kinship group that operates as a community of consent - with the added twist that, while they may not have Georgian ancestry, a small minority who marry into Georgian families have descendants who do, in fact, have Georgian blood running in their veins. The case of those who pursue their passion to its limit, arriving at a depth of cultural understanding commensurate with (or even exceeding) that of some insiders and sometimes being described by Georgians themselves as having "become almost Georgian," contributes important perspectives to debates on identity, heritage, and belonging in a fluid, post-ethnic age.

$<1>$ The Post-Revival Turn: Transnational Connections and New World Orders

A decade into the twenty-first century, Georgian polyphony might be considered to have attained the status of what Anthony Wallace (1956), in his model for revitalization movements, termed a "new steady state" where it no longer needs to fight for survival but has become part of a new norm. The transnational Georgian-singing community would seem 
nonetheless to have a part to play, at different levels, in ensuring a sustainable future. A concert given in 2007 by a group of singers from the US, Canada, the UK, France, and Germany, who (with Carl Linich) had spent two weeks studying with songmasters Islam Pilpani, Polikarpe Khubulava, and Tristan Sikharulidze, prompted the following response from Malkhaz Gulashvili, President of The Georgian Times:

Foreigners, who are getting acquainted with Georgian culture, certainly need support. It is our patriotic duty to hold them up, as our culture still lacks popularization. . . . Our goal is to acquaint the whole world with Georgians and Georgian culture. For that we need those people, who will promote it. (Quoted in Kintsurashvili 2007)

Reflecting on the same event, Rusudan Tsurtsumia characterized these developments as "moving in step with modern times" and "meeting with the new social orders" (Tsurtsumia 2010: 260). She went on to observe that the "utility value" of polyphony in contemporary Georgia is further enhanced by its "symbolic value" (ibid.: 264). This applies to both internal and external affairs. Like all revivalists, the different stakeholders in the country's cultural currency are simultaneously "reaching back" and "stretching out" (Slobin 1983: 42)—not only for musical sounds and repertoires but also for meanings and connections, kinship and community, for a sense of the natural or authentic, the sacred or transcendent - as they negotiate a place for ancient truths in the contemporary world.

Georgia's international friends have undoubtedly played a part in the latest cycle of revival. In both their literal and symbolic manifestations, they may also be configured as occupying, in some respects, the realm of post-revival. The "post" prefix does not indicate that revival is over and done with. Like the post- of postcolonialism, it suggests that the old world of revival has undergone substantive transformation and is now part of a far bigger 
story that needs to be theorized within a different kind of frame and using a different kind of language. The meeting ground on which the intercultural exchanges described here are played out might be likened to Homi Bhabha's (1994) notion of a "third space" that is emancipatory in allowing personal, social, and political transformation to take place. As such, it also sits within a broader politics of hybridity and cultural interdependence.

Ulf Hannerz has stressed that in the transnational arena it is not necessarily the corporate enterprises of nations and states that occupy center stage; rather, "the actors may now be individuals, groups, movements" (1996: 6). Certainly in Georgia, the formal advances of the post-UNESCO years are only half the story. The top-down initiatives that have helped achieve the new steady state have their complement in the continued potency of grassroots activity. Mark Slobin has pointed out that an intriguing dimension of the phenomenon whereby musics "seem to call out to audiences across nation-state lines even when they are not part of heritage or of a commodified, disembodied network" is that this is particularly likely to happen "when the transmission is of the old-fashioned variety-face to face, mouth to ear" (1993: 68). Again, the Georgian case offers a striking example, with the space in which national and supposedly global agendas meet with individual passions, aspirations, and primordial desires for human contact emerging as the most productive focal point.

Stuart Hall has written of identities as being less about "roots" (where we have come from) and more about "routes" (where we are going) (Hall 1996: 4). It is in this journey towards the future, with its connotations of new beginnings rather than neat endings and its tantalizing promise of self-determination, that the potential of the post-revival moment lies. When patriotic writer Petre Umikashvili declared (in 1882) that "revival is . . when we will hear Georgian singing and chanting at all party dinners and feasts, indoors and outdoors, in the church and theatre, in streets and on ships" (Tsitsishvili 2010: 59), little did he guess that these same songs and chants would later be heard not only on concert stages across the world 
but also on barges and bridges, in castles and caves, and in countless other unlikely places thousands of miles from their source. I leave the reader to speculate about how many more acts there may be in this play of voices before a spacecraft lands, a box is opened, a disc is spun, and the harmonies of "Chakrulo" vibrate across the landscape of a world yet to be imagined.

References

Bhabha, Homi K. 1994. The Location of Culture. London: Routledge.

Bithell, Caroline. 2012. "Songs, Sounds and Sentiments in Translation: The Transnational Travels of Corsican and Georgian Polyphony.” Journal of Mediterranean Studies 21, no. 2: [pages].

Erkvanidze, Malkhaz. 2002-2011. Georgian Church Chant. 6 volumes. Tbilisi: Georgian Patriarchate.

Gabisonia, Tamaz. 2007. “A Song Dies When Young People Forget It.” Interview with Anzor Erkomaishvili. Bulletin of the International Research Centre for Traditional Polyphony 6 (June): 27-31. Tbilisi: V. Sarajishvili Tbilisi State Conservatoire.

Garakanidze, Edisher. 2004. "Introduction.” 99 Georgian Songs: A Collection of Traditional Folk, Church and Urban Songs from Georgia. Aberystwyth: Black Mountain Press. Hall, Stuart. 1996. “Introduction: Who Needs 'Identity'?” In Questions of Cultural Identity, edited by Stuart Hall and Paul du Gay, 1-17. London: Sage.

Hannerz, Ulf. 1996. Transnational Connections: Culture, People, Places. London and New York: Routledge.

Hollinger, David A. 2005. Postethnic America: Beyond Multiculturalism. Tenth anniversary edition. New York: Basic Books. 
Koridze, Pilimon I. 1895: Kartuli Galoba, Liturgia Partitura No. 1. Tbilisi: Sharadze and Friends Press.

Jordania, Joseph. 2000. “Georgia.” In The Garland Encyclopedia of World Music, vol. 8: Europe, edited by Timothy Rice, James Porter, and Chris Goertzen, 826-849. New York and London: Garland Publishing.

Kane, Frank. 2003. "Learning Techniques for Georgian Singing Used by Georgian Choruses Abroad.” In The First International Symposium on Traditional Polyphony (Proceedings), edited by Rusudan Tsurtsumia and Joseph Jordania, 558-563. Tbilisi: Tbilisi State Conservatoire. http://www.polyphony.ge/uploads/simposium/engl1/kane_learning.pdf.

Kintsurashvili, Mari. 2007. Column in the Culture section of The Georgian Times, June 25. http://www.geotimes.ge/index.php?m=home\&newsid=5286.

Levin, Ted. 1989. Liner notes to The Rustavi Choir, Georgian Voices. Elektra Nonesuch 979224-2.

Livingston, Tamara E. 1999. “Music Revivals: Towards a General Theory.” Ethnomusicology 43, no. 1: $66-85$.

Mills, Joan. 2004. "Preface." 99 Georgian Songs: A Collection of Traditional Folk, Church and Urban Songs from Georgia. Aberystwyth: Black Mountain Press.

Nadel, Siegfried F. 1933. Georgische Gesänge. Leipzig: Otto Harrassowitz.

Ninoshvili, Lauren. 2010. "Singing between the Words: The Poetics of Georgian Polyphony." PhD diss., Columbia University, USA.

Ronström, Owe. 1996. "Revival Reconsidered." The World of Music 38, no. 3: 5-20.

Root, Deborah. 1996. Cannibal Culture: Art, Appropriation, and the Commodification of Difference. Boulder, Colorado, and Oxford: Westview Press. 
Schneider, Marius. 1940. "Kaukasische Parallelen zum europäischen Mittelalter.” Acta Musicologica 12: 52-61.

Slobin, Mark. 1983. 'Rethinking 'Revival' of American Ethnic Music.” New York Folklore 9, no. 3-4: 37-44.

1993. Subcultural Sounds: Micromusics of the West. Hanover, NH: Wesleyan University Press.

Tsitsishvili, Nino. 2010. National Unity and Gender Difference: Ideologies and Practices in Georgian Traditional Music. Saarbrücken: Lap Lambert Academic Publishing.

Tsurtsumia, Rusudan. 2010. “Georgian Multipart Singing and National Identity.” In Echoes from Georgia: Seventeen Arguments on Georgian Polyphony, edited by Rusudan Tsurtsumia and Joseph Jordania, 257-267. New York: Nova Science Publishers. Tsurtsumia, Rusudan, et al. (eds.). 2000. Problems of Folk Polyphony. Materials of the International Conference Dedicated to the $80^{\text {th }}$ Anniversary of the V. Saradjishvili Tbilisi State Conservatoire. V. Saradjishvili Tbilisi State Conservatoire: Tbilisi. 2001. Problems of Polyphony in Sacred and Secular Music. Reports of the International Scientific Conference Dedicated to the $3000^{\text {th }}$ Anniversary of Georgia's Statehood and the $2000^{\text {th }}$ Anniversary of Christ's Birth. Tbilisi V. Saradjishvili State Conservatoire: Tbilisi.

UNESCO. 2008. "Safeguarding and Promotion of Georgian Traditional Polyphony." Intangible Heritage Section, UNESCO. http://www.unesco.org/culture/ich/index.php?lg=en\&pg=00011\&RL=00008

Wallace, Anthony F. C. 1956. "Revitalization Movements.” American Anthropologist 58: $264-81$.

Zemtsovsky, Izaly I. 2010. “The Georgian Model: Toward the Ethnogeomusical Approach to the World of Polyphony." In Echoes from Georgia: Seventeen Arguments on 
Georgian Polyphony, edited by Rusudan Tsurtsumia and Joseph Jordania, 249-256. New York: Nova Science Publishers.

Discs cited

Chandra, Sheila. 1992. Weaving My Ancestors' Voices. Real World CDRW24.

Drinking Horns and Gramophones: The First Recordings in the Georgian Republic, 19021914. 2001. New York: Traditional Crossroads 80702-4307-2.

Echoes from the Past: Georgian Folk Music from Phonograph Wax Cylinders. 2006, 2007, 2008. Three boxed sets totalling 16 CDs. Tbilisi: International Research Center for Traditional Polyphony.

Let Us Study Georgian Folk Songs: Gurian Songs. 2004. Tbilisi: International Center for Georgian Folk Song.

Teach Yourself Georgian Folk Songs: Megrelian Songs. 2004. Tbilisi: International Center for Georgian Folk Song.

Trio Kavkasia. 2006. The Fox and the Lion. Traditional Crossroads 4331.

Films cited

Janelidze, Nana. 2010. Knights of Georgian Chant. Tbilisi: STUQO.

Zemp, Hugo. 1998. The Feast-Day of Tamar and Lashari. http://www.der.org/films/feastday-of-tamar-and-lashari.html.

An extended discography with recommendations for further listening and an annotated list of Georgian music websites can be found on the companion website. [INSERT OWM COMPUTER ICON HERE - WEB TEXTS 26.01 AND 26.02] 
This study is informed by my association with the Georgian singing network in the UK from 1995 and four visits to Georgia made between 1998 and 2011. I am grateful to the British Academy for the Small Research Grant that funded more concentrated fieldwork in 20102011. Special thanks are due to Rusudan Tsurtsumia and colleagues at Tbilisi State Conservatoire and to members of the international Georgian singing community for their willing collaboration with my enquiries. Joseph Jordania, Carl Linich, and Frank Kane offered helpful comments on an earlier version of the manuscript. I am particularly indebted to the work of Joseph Jordania and Nino Tsitsishvili for furnishing me with a firm historical foundation. Lauren Ninoshvili's excellent doctoral dissertation came to my attention in the final stages of my writing and helped fill a few remaining gaps; Carl Linich also shared with me his unpublished paper on "Authenticity in Georgian Folk Singing”. I owe my own introduction to Georgia to the late singer and ethnomusicologist Edisher Garakanidze. ${ }^{1}$ Voyager 1 and 2 carry a twelve-inch gold-plated copper disc containing a selection of sounds and images intended to portray the diversity of life and culture on Earth (see http://voyager.jpl.nasa.gov/spacecraft/goldenrec.html). For the UNESCO profile on Georgian Polyphonic Singing, see http://www.unesco.org/culture/ich/index.php?RL=00008. ${ }^{2}$ For a comprehensive and accessible introduction to Georgian musical traditions, see Jordania 2000.

${ }^{3}$ Christianity was introduced to Georgia in the first century; formal conversion followed in $337 \mathrm{CE}$, making Georgia the world's second Christian nation (after Armenia). Pre-Christian, pagan rituals can still be observed in remote mountain regions, and some old ritual songs include words thought to be the names of ancient gods related to e.g. the cult of the sun. For an example of a ritual that combines Orthodox Christian elements with more ancient 
polytheistic beliefs, see Hugo Zemp's documentary film The Feast-Day of Tamar and Lashari (1998).

${ }^{4}$ The story of the chant revival as described here is told in the film Knights of Georgian Chant (2010).

${ }^{5}$ For an introduction to the philosophy of George Soros and the work of the Open Society Foundations, see http://www.georgesoros.com/ and http://www.opensocietyfoundations.org/. ${ }^{6}$ At the 1998 symposium, I had been the only presenter from outside Georgia.

${ }^{7}$ The bulk of the funding for this project (just over USD 166,000) was provided by the Japan Funds-in-Trust.

${ }^{8}$ See Kavaksia's highly acclaimed 2006 release The Fox and the Lion for a selection of finely tuned examples representing Georgia's diverse song genres and regional styles.

${ }^{9}$ Fellow Kavkasia members Alan Gasser and Stuart Gelzer are also Silver Medal holders.

${ }^{10}$ For further discussion of Frank Kane's methods, see Bithell 2012.

${ }^{11}$ In 2012, Gigi Garakanidze, who continued his father's work both in Georgia and overseas, would also meet an early death at the age of only thirty. 